\title{
Menentukan Prediksi Kredit Nasabah Menggunakan Metode Analytical Hierarchy Prosess (AHP) pada PD BPR Kerta Raharja
}

\author{
Afrilia Astari ${ }^{1}$; Harco Leslie Hendric Spits Warnars ${ }^{2}$ \\ ${ }^{1}$ Management Trainee ERP SAGE Department, PT. Mulia Cemerlang Abadi Industri. \\ ${ }^{2}$ Computer Science Department, BINUS Graduate Program - Doctor of Computer Science \\ Bina Nusantara University Jakarta, Indonesia 11480 \\ ${ }^{1}$ afrilia@raharja.info \\ ${ }^{2}$ spits.hendric@binus.ac.id
}

\begin{abstract}
Today's technology is increasing and developing rapidly and the need for information is increasing not only in companies but in banking institutions as well. Regional Company Bank Perkreditan Rakyat (PD. $B P R)$ Kerta Raharja is a Regional Company owned by the Government of Tangerang Regency together with the Government of Banten Province, West Java Province and PT. Bank Jabar Banten, in accordance with Tangerang Regency Regional Regulation, Number 06 of 2007, dated June 6, 2007. As banking institution, BPR Kerta Raharja has many problems and one of them is in determining credit prediction activities that still use a manual prediction system in determining eligibility and has not been computerized properly. In this case, the use of the Prediction Determination System is very necessary to determine the prediction of the eligibility of credit loans. It is necessary to use a biased method that is even able to support the determination of customer credit predictions more effectively. In this paper, Analytical Hierarchy Process (AHP) method was applied in order to perform compound criteria in detail with a framework for thinking and calculating comprehensive weight criteria, by comparing sub-criteria divided into categories: good, good enough, and less in determining credit predictions. We conducted this research using observation, interview, literature study methods, and using Unified Modeling Language (UML) in describing the running system diagram procedure. The results of our research are by applying a new system to PD BPR Kerta Raharja, and making the process of determining customer credit predictions more effective and accurate.
\end{abstract}

Keywords: Prediction Determination System, Analytical Hierarchy Process (AHP), Unified Modeling Language

\begin{abstract}
ABSTRAK
Teknologi saat ini semakin maju serta berkembang pesat dan kebutuhan akan informasi semakin meningkat bukan hanya pada perusahaan tetapi pada instansi perbankan juga demikian. Maka dari itu dibutuhkan sistem informasi untuk membantu kinerja pegawai dalam mengelola data dengan efektif dan efisien. Salah satunya dalam kegiatan penentuan prediksi kredit yang ada pada PD BPR Kerta Raharja yang sekarang masih menggunakan system prediksi manual dalam penentuan kelayakan dan belum terkomputerisasi dengan baik. Dalam hal ini pengunaan Sistem Penentuan Prediksi sangatlah dibutuhkan dalam menentukan prediksi kelayakan pemberian pinjaman kredit. Diperlukan menggunakan metode yang bias bahkan mampu mendukung dalam menentukan prediksi kredit nasabah dengan lebih efektif. Yakni dengan menggunakan sebuah metode Analytical Hierarchy Process (AHP) karena metode ini dapat melakukan kriteria majemuk secara detail dengan suatu kerangka berfikir dan perhitungan suatu kriteria bobot yang komprehensif. Dengan membandingkan sub-kriteria terbagi dalam kategori: baik, cukup baik dan kurang dalam menentukan prediksi kredit. Penelitian ini kami lakukan dengan metode observasi, wawancara dan studi pustaka serta menggunakan Unified Modelling Language (UML) dalam menggambarkan prosedur diagram sistem yang berjalan. Hasil dari penelitian kami dengan menerapkan sistem baru pada PD BPR Kerta Raharja, dan menjadikan proses menentukan prediksi kredit nasabah menjadi lebih efektif serta akurat.
\end{abstract}

Kata kunci: Sistem Penentuan Prediksi, Analytical Hierarchy Process (AHP), Unified Modelling Language 
PETIR: Jurnal Pengkajian dan Penerapan Teknik Informatika

\section{PENDAHULUAN}

Dalam suatu pelayanan menetukan prediksi kredit nasabah dalam suatu peminjaman kredit masih menggunakan sistem terdahulu yakni manual. Sehingga terdapat beberapa masalah yakni menimbulkan data yang data nasabah menentukan prediksi kredit tidak akurat. Terdapat beberapa jenis kredit yang digunakan menurut sebuah jangka waktu yang dalam pengembaliannya terbagi beberapa seperti: memerlukan jangka waktu pendek, waktu menengah dan waktu panjang. Di dalam beberapa jangka waktu yang terbagi terdapat resiko bahkan juga sering menghadapi resiko tersebut. Misalnya ada beberapa nasabah mengalami terlambat bayar serta penunggakan dikarenakan berbagai hambatan dan alasan yang disampaikan nasabah.[1].

Maka dari itu diperlukan sebuah sistem yang dapat dengan mudah digunakan untuk menentukan prediksi kelayakan pemberian kredit nasabah. Dalam hal ini penggunaan metode Analytical Hierachy Process (AHP) dalam menentukan prediksi kredit nasabah sangatlah dibutuhkan dalam keputusan pemberian pinjaman kredit. Dengan menggunakan metode Analytical Hierarchy Process (AHP) karena metode ini dapat melakukan kriteria majemuk secara detail dengan suatu kerangka berfikir dan perhitungan suatu kriteria bobot yang komprehensif. Dengan membandingkan sub-kriteria terbagi dalam kategori: baik, cukup baik dan kurang dalam menentukan prediksi kredit. Menyadari akan pentingnya sebuah inovasi informasi untuk memudahkan dalam menentukan sebuah prediksi pemberian kredit nasabah. Maka dengan ini penulis mengangkat permasalahan ini sebagai sebuah objek dalam penelitian jurnal dengan yang merupakan suatu pengembangan dari sistem yang sedang berjalan, dengan demikian penelitian ini bertujuan membuat rancangan menentukan prediksi kredit nasabah untuk membantu para pegawai dalam proses penyeleksian kelayakan dihitung dengan bobot dan kriteria agar tidak salah memberikan kredit nasabah agar meminimalisir terjadinya keterlambatan dalam pembayaran kredit di kemudian hari. [2]

\section{TINJAUAN PUSTAKA}

Berdasarkan suatu kajian penelitian terhadap penelitian sebelumnya, bahwa sudah banyak yang melakukan penelitian tentang kredit nasabah menggunakan metode Analytical Hierarchy Process (AHP) [3]. Namun secara khusus tidak pernah ditemukan penelitian pada judul Menentukan Prediksi Kredit Nasabah. Penjabaran mengenai penelitian lampau serta ada kaitan hubungan dengan penelitian yang diangkat masalahnya serta dijelaskan pada sub-bab ini:

\subsection{Penelitian Sebelumnya}

Penelitian dengan menggunakan sebuah metode Analytical Hierarchy Process (AHP) yang menggunakan perhitungan dengan memakai nilai bobot dan kriteria merupakan bukan lagi hal yang baru dalam suatu penelitian. Akan tetapi sudah banyak penelitian-penelitian sebelumnya yang menggunakan metode sejenis Analytical Hierarchy Process (AHP) dalam metode penelitiannya.

Agerti Galo., berpendapat bahwa penelitian ini dilakukan untuk mengetahui tentang statistik peringkat persetujuan aplikasi pengajuan kartu kredit dan seiring berjalannya waktu meningkatnya permintaan untuk kartu kredit. Penggunaan metode Analytical Hierarchy Process (AHP) yakni solusi untuk memenuhi suatu kebutuhan pengambilan keputusan oleh bank membuat sangat efisien serta rendah biaya [2].

Wenqing Xu, Huiqun Yu, dkk., mengemukakan pendapat bahwa penelitian ini dilakukan untuk melakukan suatu evaluasi kredit terhadap pelanggan sebagai tugas penting untuk perusahaan gas sebagai mencapai suatu manajemen pemasaran. Dengan melakukkan analisis berdasarkan berbagai faktor yang mempengaruhi yakni pelanggan gas kredit yang selanjutnya dibuat berdasarkan hierarki indeks kredit pelanggan gas. Penggunaan metode AHP menentukan bobot indeks kredit yakni dengan 
PETIR: Jurnal Pengkajian dan Penerapan Teknik Informatika

Vol. 13, No. 1, Maret 2020, P-ISSN 1978-9262, E-ISSN 2655-5018

DOI: https://doi.org/10.33322/petir.v13i1.870

analisis empiris data aktual perusahaan gas dan model ini dapat mengevaluasi secara rasional dan efektif [3].

Nuri Latifa Efrata dan Jijon Raphita Sagala., berpendapat pada penelitian ini dilakukan untuk Perusahaan Showroom menetapkan suatu kebijakan dalam pemberian suatu kredit terhadap pelanggan serta menetapkan standard seperti menerima atau menolak resiko kredit. Maka digunakanlah model metode AHP untuk menetukan siapa yang berhak dan sesuai kriteria untuk menerima kredit tersebut. Dengan menggunakan metode AHP keputusan dikategorikan layak dan tidak layak setelah itu ditentukan intensitas kepentingan atau skala prioritas pada kriteria [4].

Roohollah Mohammadi, Bijan Bidabad, dkk., mengemukakan tentang penelitian yang dilakukan untuk pemeringkatan pelanggan kredit termasuk seperti transaksi, pembayaran dan variable RFM (Kekinian, Frekuensi dan Moneter). Bobot masing variable dihitung melalui wawancara bank menggunakan FAHP serta menggunakan nilai variable dan algoritma K-means, kelompok pelanggan tentu dioptimalkan. Pada akhirnya, nasabah bank diberi peringkat dalam 5 kluster kredit dan nilai dari masing-masing kluster yang diperkirakan [5].

Xiaoxing Ma., berpendapat dalam penelitian yang dilakukan yakni untuk mempelajari suatu resiko masalah dana perumahan yang kompleks serta relatif tidak jelas, maka dibangun model struktural untuk penilaian resiko dengan menggunakan metode AHP. Di mana akan menentukan setiap evaluasi secara spesifik dari bobot kriteria yang disusun untuk mendapatkan matriks penilaian resiko dana perumahan sering terdapat faktor yang tak terduga yang tak terhindarkan. Dengan membangun program menggunakan software yang diharapkan mampu mengendalikan resiko kerugian [6].

Khalil Khalilia dan Kamal Khalilpour., mengemukakan pendapat dalam kelangsungan hidup lembaga keuangan dan bank dalam pasar kompetitif. Tujuannya yakni mengidentifikasi dan mengklarifikasi pelanggan sesuai dengan risiko kredit dan keputusan model prediksi. Dalam penelitian menggunak metode TOPSIS yakni menganalisis data kuesioner, proses hirarki analitik, dan menganalisi data keuangan pelanggan yang nyata. Populasi penelitian termasuk file pelanggan nyata di salah satu cabang Bank RefahKargaran di kota Tabriz, Iran. Dari antara 800 file, 140 file diselesaikan dan menggunakan tabel Morgan, 103 file diselidiki. Model akhir disajikan dan dengan probabilitas 95\%, jika data pelanggan berikutnya dimasukkan dalam model, ia akan mampu mengidentifikasi secara akurat tingkat risiko pelanggan [9].

Berdasarkan penelitian di atas dapat dijelaskan bahwa metode Analytical Hierarchy Process (AHP) itu sangat penting dan banyak digunakan di dunia perbankan. Karena dapat mempermudah dalam penentuan bobot dan kriteria untuk di analisis apakah sesuai atau tidaknya dengan bobot dan kriteria yang ditentukan oleh perusahaan tersebut. Namun beberapa penelitian yang dilakukan diatas banyak menggunakan metode yang berbeda-beda. Akan tetapi peneliti lebih minat menggunakan dan memakai metode Analytical Hierarchy Process (AHP) yang akan langsung dikaitkan dengan objek yang dijadikan penelitian. Dalam penelitian ini menentukan bobot dan kriteria nasabah yang kemudian akan digunakan sebagai menentukan prediksi kredit nasabah.

Penelitian yang peneliti angkat dengan berjudul " Menentukan Prediksi Kredit Nasabah Menggunakan Metode Analytical Hierarchy Process (AHP) Pada PD BPR Kerta Raharja” adalah suatu bentuk agar mempermudah perusahaan daerah perbankan dalam menentukan prediksi nasabah karena di zaman sekarang sangat rentan dan harus perlu ke hati-hatian dalam memberikan kredit, salah satunya dengan menggunakan metode AHP kita dapat menentukan bobot dan kriteria nasabah yang layak atau tidak layak untuk menerima pinjaman kredit. 
PETIR: Jurnal Pengkajian dan Penerapan Teknik Informatika Vol. 13, No. 1, Maret 2020, P-ISSN 1978-9262, E-ISSN 2655-5018 DOI: https://doi.org/10.33322/petir.v13i1.870

\section{METODE PENELITIAN}

\subsection{Kredit}

Menurut Fatmawati, kredit sebagai suatu sarana peminjaman dana atau uang kepada seseorang yang membutuhkan atau yang berarti saya percaya. Pengertian kredit menurut UU perbankan nomor 10 tahun 1998 yakni sebagai jasa penyediaan pinjaman dana yang kemudian terdapat persetujuan peminjaman antara bank dan pihak lain biasa disebut nasabah. [10]

\subsection{Analytical Hierarchy Process (AHP)}

Menurut Fatmawati, menyatakan bahwa (AHP) yakni suatu atau bentuk model dalam pendukung suatu keputusan yang di ciptakan bahkan di kembangkan oleh Thomas L. Saaty. Hierarki dapat sebuah representasi dalam satu permasalahan begitu kompleks. [11]

Penyelesaian permasalahan dengan memakai metode (AHP) terdapat prinsip, yakni: (Kusrini, 2007)

\section{Menyusun Elemen Hierarki}

Sistem begitu kompleks akan semakin mudah dipahami dan dimengerti dengan memecah beberapa elemen-elemen pendukung, penyusunan elemen secara hierarki dengan menggabung dengan lainnya. Penjelasan struktur hierarki ditunjukkan oleh Gambar 1 [12].

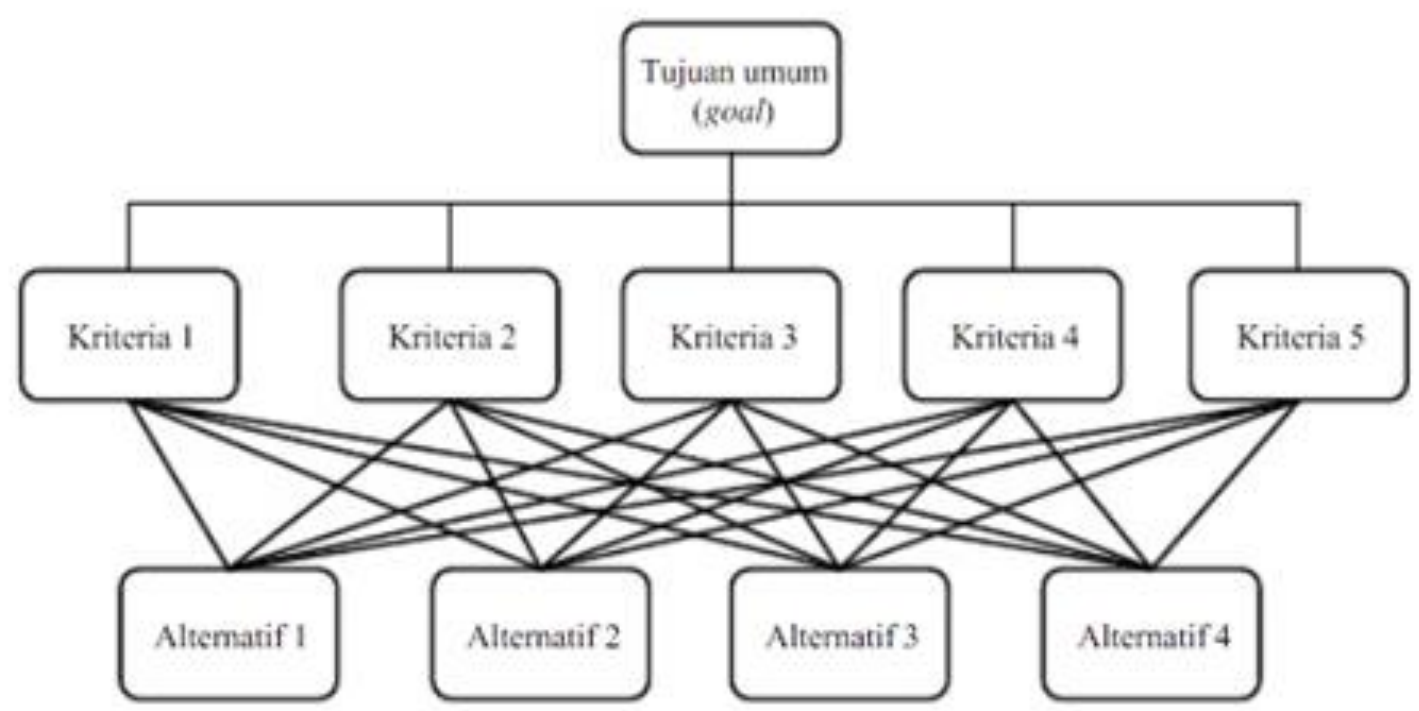

Gambar 1. Struktur hierarki

2. Penilaian Suatu Kriteria serta Alternatif Perbandingan

Penilaian suatu kriteria dan alternatif melakukan sebuah perbandingan. Untuk beberapa macam sebuah persoalan, skala tingkat kepentingan 1-9 yakni skala terbaik guna mengekspresikan suatu pendapat. [13]. 
PETIR: Jurnal Pengkajian dan Penerapan Teknik Informatika Vol. 13, No. 1, Maret 2020, P-ISSN 1978-9262, E-ISSN 2655-5018

DOI: https://doi.org/10.33322/petir.v13i1.870

Tabel 1. Skala Penilaian Perbandingan Berpasangan:

\begin{tabular}{|c|c|}
\hline $\begin{array}{c}\text { Tingkat } \\
\text { Kepentingan }\end{array}$ & \multicolumn{1}{c|}{ Definisi } \\
\hline $\mathbf{1}$ & $\begin{array}{c}\text { Kedua Elemen Sangat Penting. } \\
\text { Elemen yang satu sedikit lebih penting } \\
\text { di banding elemen lain. }\end{array}$ \\
\hline $\mathbf{5}$ & $\begin{array}{c}\text { Elemen yang satu esensial atau sangat } \\
\text { penting dibanding elemen yang } \\
\text { lainnya. }\end{array}$ \\
\hline $\mathbf{7}$ & $\begin{array}{c}\text { Elemen yang satu benar-benar lebih } \\
\text { penting dari yang lainnya. }\end{array}$ \\
\hline $\mathbf{9}$ & $\begin{array}{c}\text { Elemen yang satu mutlak lebih penting } \\
\text { disbanding elemen yang lain. } \\
\text { Nilai tengah diantara dua penilaian } \\
\text { berurutan. Jika aktivitas i mendapat } \\
\text { satu angka dibandingkan dengan } \\
\text { aktivitas j, maka j memiliki nilai } \\
\text { kebalikannya di bandingkan dengan i. }\end{array}$ \\
\hline $\mathbf{2 , 4 , 6 , 3}$ & \\
\hline
\end{tabular}

3. Penentuan Kriteria Prioritas (Determine Priority Criteria).

Dalam menentukan suatu kriteria serta Prioritas alternatif akan dipergunakan harus melakukan sebuah banding berpasangan. [14]

$$
A=\left[a_{1 j}\right]=\left(\begin{array}{cccccc}
1 & a_{12} & \ldots & a_{1 j} & \ldots & a_{l n} \\
1 / a_{12} & 1 & \ldots & a_{2 j} & \ldots & a_{2 n} \\
1 / a_{1 j} & 1 / a_{2 j} & \ldots & a_{3 j} & \ldots & a_{n n} \\
1 / a_{1 n} & 1 / a_{2 n} & \ldots & 1 / a_{n n} & \ldots & 1
\end{array}\right)
$$

4. Pertimbangan pada perbandingan berpasangan disintesis untuk keseluruhan prioritas.
a. Menghitung eigen $\sum=\sum$ baris/ $\sum$ kriteria
b. Menghitung bobot prioritas Bobot prioritas = matrik perbandingan berpasangan $\mathrm{x}$ eigen dan hasilnya dibagidengan eigen.
c. Menghitung $\sum$ (eigen) maksimal $=\sum$ bobotprioritas $-\sum$ kriteria .

5. Menghitung Consistency Indeks CI dengan rumus:

$$
\mathrm{CI}=\left(\boldsymbol{\lambda}_{\text {maks }}-\mathbf{n}\right) /(\mathbf{n}-\mathbf{1})
$$

Keterangan $\mathbf{n}=$ banyak elemen 
PETIR: Jurnal Pengkajian dan Penerapan Teknik Informatika Vol. 13, No. 1, Maret 2020, P-ISSN 1978-9262, E-ISSN 2655-5018

6. Menghitung Rasio Konsistensi / Consistency Ratio (CR) dengan rumus:

$$
\mathbf{C R}=\mathbf{C I} / \mathbf{I R}
$$

Keterangan:

- $\mathrm{CR}=$ Consistency Ratio

- $\mathrm{CI}=$ Consistency Index

- IR = Index Random Consistency

\section{HASIL DAN PEMBAHASAN}

\subsection{Analisis Sistem Yang Berjalan}

Analisis pada sistem merupakan suatu kegiatan menguraikan sebuah informasi yang seutuhnya serta nyata kedalam komponen yang akan mengidentifikasi. Berikut adalah prosedur dalam pemberian kredit pada PD BPR Kerta Raharja.

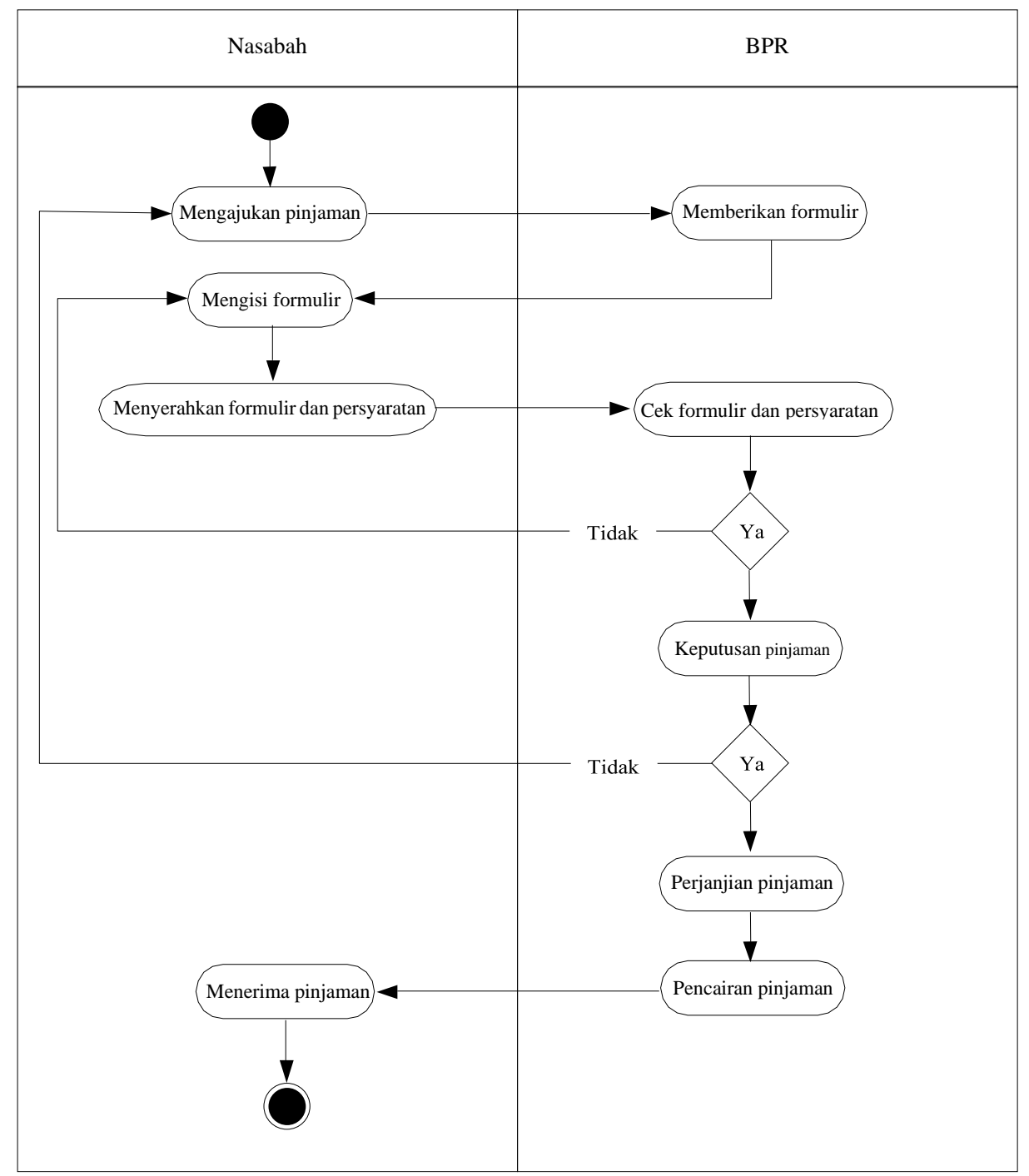

Gambar 2. Diagram Aktivitas Skenario

Proses Kelayakan Penentuan Kredit 
PETIR: Jurnal Pengkajian dan Penerapan Teknik Informatika

Vol. 13, No. 1, Maret 2020, P-ISSN 1978-9262, E-ISSN 2655-5018

DOI: https://doi.org/10.33322/petir.v13i1.870

\subsection{Analisis Pemecahan Masalah Menggunakan Metode AHP}

1. Nilai Matriks Kriteria

Susun dan menjumlahkan kriteria-kriteria prediksi nasabah penerima kredit pada matriks berpasangan.

Tabel 2. Nilai Matriks Perbandingan Berpasangan

\begin{tabular}{|c|c|c|c|c|c|c|c|c|c|c|c|c|c|c|c|}
\hline & usia & $\begin{array}{l}\text { perker } \\
\text { jaan }\end{array}$ & \begin{tabular}{|l} 
status \\
keangg \\
taan \\
\end{tabular} & $\begin{array}{l}\text { pendi } \\
\text { dikan }\end{array}$ & $\begin{array}{l}\text { produk } \\
\text { tivitas }\end{array}$ & $\begin{array}{l}\text { kolek } \\
\text { tabilitas }\end{array}$ & $\begin{array}{l}\text { besar } \\
\text { simp }\end{array}$ & $\begin{array}{l}\text { jangka } \\
\text { waktu }\end{array}$ & $\begin{array}{l}\text { besar } \\
\text { bunga }\end{array}$ & \begin{tabular}{|l|} 
pengha \\
silan
\end{tabular} & $\begin{array}{l}\text { penge } \\
\text { luaran }\end{array}$ & $\begin{array}{l}\text { tang } \\
\text { gungan }\end{array}$ & jami & $\begin{array}{l}\text { status } \\
\text { kredit }\end{array}$ & $\begin{array}{l}\text { kredi } \\
\text { bilitas }\end{array}$ \\
\hline usia & & 4 & 2 & 2 & 5 & 5 & 3 & 3 & 3 & 5 & 5 & 3 & 6 & 2 & \\
\hline perkerjaa & 0.25 & 1 & 0.5 & 03 & 3 & 3 & 05 & 0.5 & 2 & 3 & 3 & 05 & 4 & 03 & \\
\hline status keanggotaan & 0.5 & 2 & 1 & 05 & 3 & 3 & 3 & 2 & 3 & 3 & 4 & 3 & 6 & 1 & 4 \\
\hline pendidikan & 0.5 & 33 & 2 & 1 & 4 & 4 & 3 & 3 & 3 & 5 & 5 & 3 & 6 & 2 & 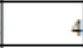 \\
\hline produktivitas & 0.2 & 3 & 0.3 & 0.25 & 1 & 2 & 03 & 0.3 & 0.5 & 1 & 1 & 03 & 3 & 03 & \\
\hline kolektabilitas & 0.2 & 3 & 0.3 & 0.25 & 0.5 & 1 & 03 & 0.3 & 0.5 & 0.5 & 0.5 & 0.25 & 2 & 0.25 & \\
\hline besar simpanan & 3 & 05 & 0.3 & 03 & 3.3 & 3.3 & 1 & 0.5 & 2 & 4 & 3 & 2 & 4 & 03 & 4 \\
\hline jangka waktu & 0.3 & 2 & 0.5 & 03 & 3.3 & 3.3 & 2 & 1 & 2 & 4 & 4 & 2 & 5 & 0.5 & \\
\hline besar bunga & 0.3 & 05 & 0.3 & 0.3 & 2 & 2 & 05 & 0.5 & 1 & 2 & 2 & 03 & 4 & 03 & 3 \\
\hline penghasilan & 0.2 & 03 & 0.3 & 02 & 1 & 2 & 0.25 & 0.25 & 0.5 & 1 & 1 & 03 & 3 & 0.25 & \\
\hline pengeluaran & 0.2 & 03 & 0.25 & 02 & 1 & 2 & 03 & 0.25 & 0.5 & 1 & 1 & 05 & 3 & 025 & \\
\hline tanggungan & 0.3 & 2 & 0.3 & 03 & 3.3 & 4 & 0.5 & 0.5 & 3.3 & 3.3 & 2 & 1 & 5 & 0.3 & 3 \\
\hline jaminan & 6 & 0.25 & 0.17 & 0.17 & 0.3 & 0.5 & 0.25 & 0.2 & 0.25 & 0.3 & 03 & 02 & 1 & 0.17 & 0.5 \\
\hline status kredit & 2 & 33 & 1 & 05 & 3.3 & 4 & 33 & 0.3 & 3.3 & 4 & 4 & 33 & 58 & 1 & 3 \\
\hline kredibilitas & 0.2 & 03 & 0.25 & 0.25 & 0.5 & 1 & 0.25 & 0.25 & 0.3 & 0.5 & 0.5 & 03 & 2 & 03 & \\
\hline jumlah & 1515 & 2575 & 9.47 & 6.82 & 34.5 & 42.1 & 18.45 & 1285 & 25.15 & 37.6 & 363 & 1995 & $\$ 9.8$ & 92 & 415 \\
\hline
\end{tabular}

2. Normalisasi

Setelah menyusun nilai matriks kiteria, maka tahap selanjutnya adalah menghitung nilai normalisasi matriks dengan cara membagi hasil pada nilai tersendiri per sub kriteria dengan hasil jumlah tersendiri pada kolom tertera.

Tabel 3. Nilai Normalisasi Matriks Berpasangan

\begin{tabular}{|c|c|c|c|c|c|c|c|c|c|c|c|c|c|c|c|c|}
\hline & usia & $\begin{array}{l}\text { perker } \\
\text { jaan }\end{array}$ & $\begin{array}{l}\text { status } \\
\text { keang } \\
\text { gotan }\end{array}$ & $\begin{array}{l}\text { pendil } \\
\text { dikan }\end{array}$ & $\begin{array}{l}\text { produk } \\
\text { fivitas }\end{array}$ & $\begin{array}{l}\text { kolek } \\
\text { tabi } \\
\text { litas }\end{array}$ & $\begin{array}{l}\text { besar } \\
\text { sim } \\
\text { panan }\end{array}$ & $\begin{array}{l}\text { jangka } \\
\text { wakth }\end{array}$ & $\begin{array}{l}\text { besar } \\
\text { bunga }\end{array}$ & $\begin{array}{l}\text { pengha } \\
\text { silan }\end{array}$ & $\begin{array}{l}\text { penge } \\
\text { luaran }\end{array}$ & \begin{tabular}{|l|} 
tang \\
gungan
\end{tabular} & jami & $\begin{array}{l}\text { status } \\
\text { laredit }\end{array}$ & $\begin{array}{l}\text { kredi } \\
\text { bilitas }\end{array}$ & IUIAA \\
\hline usia & 0.07 & 0.155 & 0.2112 & 0.293 & 0.1449 & 0.1247 & 0.16 & 0.233 & 0.119 & 0.133 & 0.138 & 0.1504 & 0.1 & 0.2169 & 0.12 & $23695913 \pi$ \\
\hline perkerjaa & 0.02 & 0.039 & 0.0528 & 0.044 & 0.087 & 0.0748 & 0.03 & 0.039 & 0.08 & 0.0798 & 0.083 & \begin{tabular}{l|l|} 
& 0.0251 \\
\end{tabular} & 0.067 & 0.0325 & 0.072 & 0.818637579 \\
\hline status keanggotaan & 0.03 & 0.078 & 0.1056 & 0.073 & 0.087 & 0.0748 & 0.16 & 0.156 & 0.119 & 0.0798 & 0.11 & 0.1504 & 0.1 & 0.1085 & 0.096 & 1534416912 \\
\hline pendidikan & 0.03 & 0.128 & 0.2112 & 20.147 & 0.1159 & 0.0998 & 0.16 & 0.233 & 0.119 & 0.133 & 0.138 & 0.1504 & 0.1 & 0.2169 & 0.096 & 2.084756496 \\
\hline produktivitas & 0.01 & 0.117 & 0.0317 & 0.037 & 0.029 & 0.0499 & 0.02 & 0.023 & 0.02 & 0.0266 & 0.028 & 0.015 & 0.05 & 0.0325 & 0.048 & 0.536469557 \\
\hline kolektabilitas & 0.01 & 0.117 & 0.0317 & 0.037 & 0.0145 & 0.0249 & 0.02 & 0.023 & 0.02 & 0.0133 & 0.014 & 0.0125 & 0.033 & 0.0271 & 0.024 & 0.421219118 \\
\hline besar simpanan & 0.2 & 0.019 & 0.0317 & 0.044 & 0.0957 & 0.0823 & 0.05 & 0.039 & 0.08 & 0.1064 & 0.083 & 0.1003 & 0.067 & 0.0325 & 0.096 & 1.128776251 \\
\hline langka waktu & 0.02 & 0.078 & 0.0528 & 0.044 & 0.0957 & 0.0823 & 0.11 & 0.078 & 0.08 & 0.1064 & 0.11 & 0.1003 & 0.084 & 0.0542 & 0.096 & 1.18900382 \\
\hline besar bunga & 0.02 & 0.019 & 0.0317 & 0.044 & 0.058 & 0.0499 & 0.03 & 0.039 & 0.04 & 0.0532 & 0.055 & 0.015 & 0.067 & 0.0325 & 0.072 & 0.623547498 \\
\hline penghasilan & 0.01 & 0.012 & 0.0317 & 0.029 & 0.029 & 0.0499 & 0.01 & 0.019 & 0.02 & 0.0266 & 0.028 & 0.015 & 0.05 & 0.0271 & 0.048 & 0.412259739 \\
\hline pengeluaran & 0.01 & 0,012 & 0.0264 & 0.029 & 0.029 & 0.0499 & 0.02 & 0.019 & 0.02 & 0.0266 & 0.028 & 0.0251 & 0.05 & 0.0271 & 0.048 & 0.419714998 \\
\hline tanggungan & 0.02 & 0.078 & 0.0317 & 0.044 & 0.0957 & 0.0998 & 0.03 & 0.039 & 0.131 & 0.0878 & 0.055 & $5 \mid 0.0501$ & 0.084 & 0.0325 & 0.072 & 0.947192284 \\
\hline jaminan & 0.4 & 0.01 & 0.018 & 0.025 & 0.0087 & 0.0125 & 0.01 & 0.016 & 0.01 & 0.008 & 0.008 & 0.01 & 0.017 & 0.0184 & 0.012 & 0.582322657 \\
\hline status kredit & 0.13 & 0.128 & 0.1056 & 50.073 & 0.0957 & 0.0998 & 0.18 & 0.023 & 0.131 & 0.1064 & 0.11 & 0.1654 & 0.097 & 0.1085 & 0.072 & 1.627630901 \\
\hline kredibilitas & 0.01 & 0.012 & 0.0264 & 0.037 & 0.0145 & 0.0249 & 0.01 & 0.019 & 0.012 & 0.0133 & 0.014 & 0.015 & 0.033 & 0.0325 & 0.024 & 0.304460813 \\
\hline
\end{tabular}


PETIR: Jurnal Pengkajian dan Penerapan Teknik Informatika

3. Menghitung Vektor Bobot Kriteria

Setelah mendapat nilai normalisasi, kemudian langkah selanjutnya adalah menghitung nilai vektor bobot kriteria dengan cara dengan membagi jumlah nilai dari setiap baris dengan dengan banyak kriteria yang tersedia. Kriteria usia adalah kriteria paling penting dalam prediksi pemeberian kredit karena memiliki nilai bobot paling unggul atau tinggi dibandingkan dengan prioritas lainnya.

Tabel 4. Nilai Vektor Bobot Kriteria

\begin{tabular}{|l|r|}
\hline \multicolumn{1}{|c|}{ kriteria } & \multicolumn{1}{c|}{ vektor bobot } \\
\hline usia & 0.157972758 \\
\hline perkerjaa & 0.054575839 \\
\hline status keanggotaan & 0.102294461 \\
\hline pendidikan & 0.138983766 \\
\hline produktivitas & 0.035764637 \\
\hline kolekta bilitas & 0.028081275 \\
\hline besar simpanan & 0.07525175 \\
\hline jangka waktu & 0.079266921 \\
\hline besar bunga & 0.041569833 \\
\hline penghasilan & 0.027483983 \\
\hline pengeluaran & 0.027981 \\
\hline tanggungan & 0.063146152 \\
\hline jaminan & 0.03882151 \\
\hline status kredit & 0.108508727 \\
\hline kredibilitas & 0.020297388 \\
\hline
\end{tabular}

4. Memeriksa Konsistensi

Setelah mendapatkan nilai vektor bobot kriteria, kemudian langkah selanjutnya adalah memeriksa konsistensi hierarki dengan cara mengalikan nilai masukan matriks dengan nilai vektor bobot kriteria.

Tabel 5. Nilai Konsistensi Matriks

\begin{tabular}{|c|c|c|c|c|c|c|c|c|c|c|c|c|c|c|c|c|}
\hline & usia & $\begin{array}{l}\text { perker } \\
\text { jaan }\end{array}$ & $\begin{array}{l}\text { status } \\
\text { keang } \\
\text { gotaan }\end{array}$ & $\begin{array}{l}\text { pendi } \\
\text { dikan }\end{array}$ & $\begin{array}{l}\text { produk } \\
\text { tivitas }\end{array}$ & $\begin{array}{l}\text { kolek } \\
\text { tabi } \\
\text { litas }\end{array}$ & $\begin{array}{l}\text { besar } \\
\text { sim } \\
\text { panan }\end{array}$ & $\begin{array}{l}\text { jangka } \\
\text { waktu }\end{array}$ & 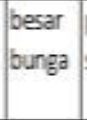 & $\begin{array}{l}\text { pengha } \\
\text { silan }\end{array}$ & $\begin{array}{l}\text { penge } \\
\text { luaran }\end{array}$ & $\begin{array}{l}\text { tang } \\
\text { gungan }\end{array}$ & $\begin{array}{l}\text { jami } \\
\text { nan }\end{array}$ & $\begin{array}{l}\text { status } \\
\text { kredit }\end{array}$ & $\begin{array}{l}\text { kredi } \\
\text { bilitas }\end{array}$ & JUMLAH \\
\hline status keanggotaan & 0.17 & 0.4 & 0.2667 & 0.133 & 0.4 & 0.2 & 0.8 & 0.533 & 0.6 & 0.4 & 0.533 & 0.6 & 0.2 & 0.2 & 0.2667 & 5.7 \\
\hline pendidikan & 0.17 & 0.66 & 0.5333 & 0.267 & 0.5333 & 0.267 & 0.8 & 0.8 & 0.6 & 0.6667 & 0.667 & 0.6 & 0.2 & 0.4 & 0.2667 & 7.426666667 \\
\hline produktivitas & 0.07 & 0.6 & 0.08 & 0.067 & 0.1333 & 0.133 & 0.08 & 0.08 & 0.1 & 0.1333 & 0.133 & 0.06 & 0.1 & 0.06 & 0.1333 & 1.96 \\
\hline kolektabilitas & 0.07 & 0.5 & 0.08 & 0.067 & 0.0667 & 0.067 & 0.08 & 0.08 & 0.1 & 0.0667 & 0.067 & 0.05 & 0.067 & 0.05 & 0.0667 & 1573333333 \\
\hline besar simpanan & 1 & 0.1 & 0.08 & 0.08 & 0.44 & 0.22 & 0.2667 & 0.133 & 0.4 & 0.5333 & 0.4 & 0.4 & 0.133 & 0.06 & 0.2667 & 4513333333 \\
\hline jangka waktu & 0.1 & 0.4 & 0.1333 & 0.08 & 0.44 & 0.22 & 0.5333 & 0.267 & 0.4 & 0.5333 & 0.533 & 0.4 & 0.167 & 0.1 & 0.2667 & 4573333333 \\
\hline besar bunga & 0.1 & 0.1 & 0.08 & 0.08 & 0.2667 & 0.133 & 0.1333 & 0.133 & 0.2 & 0.2667 & 0.267 & 0.06 & 0.133 & 0.06 & 0.2 & 2213333333 \\
\hline penghasilan & 0.07 & 0.06 & 0.08 & 0.053 & 0.1333 & 0.133 & 0.0667 & 0.067 & 0.1 & 0.1333 & 0.133 & 0.06 & 0.1 & 0.05 & 0.1333 & 1.37 \\
\hline pengeluaran & 0.07 & 0.06 & 0.0667 & 0.053 & 0.1333 & 0.133 & 0.08 & 0.067 & 0.1 & 0.1333 & 0.133 & 0.1 & 0.1 & 0.05 & 0.1333 & 1.41 \\
\hline tanggungan & 0.1 & 0.4 & 0.08 & 0.08 & 0.44 & 0.267 & 0.1333 & 0.133 & 0.66 & 0.44 & 0.267 & 0.2 & 0.167 & 0.06 & 02 & 3.5266666667 \\
\hline jaminan & 2 & 0.05 & 0.0453 & 0.045 & 0.04 & 0.033 & 0.0667 & 0.053 & 0.05 & 0.04 & 0.04 & 0.04 & 0.033 & 0.034 & 0.0333 & 2.6046666667 \\
\hline status kredit & 0.67 & 0.66 & 0.2667 & 0.133 & 0.44 & 0.267 & 0.88 & 0.08 & 0.66 & 0.5333 & 0.533 & 0.66 & 0.193 & 0.2 & 0.2 & 6.373333333 \\
\hline kredibilitas & 0.07 & 0.06 & 0.0667 & 0.067 & 0.0667 & 0.067 & 0.0667 & 0.067 & 0.06 & 0.0667 & 0.057 & 0.06 & 0.067 & 0.06 & 0.0667 & 0.973333333 \\
\hline
\end{tabular}


PETIR: Jurnal Pengkajian dan Penerapan Teknik Informatika Vol. 13, No. 1, Maret 2020, P-ISSN 1978-9262, E-ISSN 2655-5018

5. Nilai Lamda

Setelah mendapat nilai konsistensi matriks, kemudian langkah selanjutnya adalah mencari nilai lamda maksimal dengan cara membagi jumlah tiap baris nilai konsistensi matriks dengan jumlah kriteria.

Tabel 6. Nilai Lamda Kriteria

\begin{tabular}{|l|r|}
\hline \multicolumn{1}{|c|}{ Kriteria } & \multicolumn{1}{c|}{ Lamda } \\
\hline usia & 0.551111111 \\
\hline perkerjaa & 0.203777778 \\
\hline status keanggotaan & 0.38 \\
\hline pendidikan & 0.495111111 \\
\hline produktivitas & 0.130666667 \\
\hline kolektabilitas & 0.104888889 \\
\hline besar simpanan & 0.300888889 \\
\hline jangka waktu & 0.304888889 \\
\hline besar bunga & 0.147555556 \\
\hline penghasilan & 0.091333333 \\
\hline pengeluaran & 0.094 \\
\hline tanggungan & 0.241777778 \\
\hline jaminan & 0.173644444 \\
\hline status kredit & 0.424888889 \\
\hline kredibilitas & 0.064888889 \\
\hline jumlah & $\mathbf{3 . 7 0 9 4 2 2 2 2 2}$ \\
\hline lamda max & $\mathbf{0 . 2 4 7 2 9 4 8 1 5}$ \\
\hline
\end{tabular}

Rumus Perhitungan:

a. Nilai $\mathrm{CI}=($ Lamda $\max -\mathrm{n}) /(\mathrm{n}-1)$

$$
\begin{aligned}
& =(0,247294815-15) /(15-1) \\
& =-14,75270519 / 14 \\
& =-1,053764656
\end{aligned}
$$

b. Nilai $\mathrm{CR}=\mathrm{CI} / \mathrm{RI}$

$$
\begin{aligned}
& =-1,053764656 / 1,59 \\
& =-0,662745067(\mathrm{CR}<0,1, \text { Nilai Acceptable })
\end{aligned}
$$

\subsubsection{Rancangan UML (Unified Modelling Language)}

Rancangan diagram UML pada bab ini merupakan algoritma UML yang akan menjelaskan alur program yang akan dibangun yang sesuai dengan kebutuhan. Dalam sistem menentukan kelayakan nasabah kredit ini, penulis menjelaskan dengan beberapa bentuk algoritma uml antara lain adalah menggunakan usecase diagram, activity diagram dan class diagram. 
PETIR: Jurnal Pengkajian dan Penerapan Teknik Informatika

\subsubsection{Rancangan Usecase Diagram}

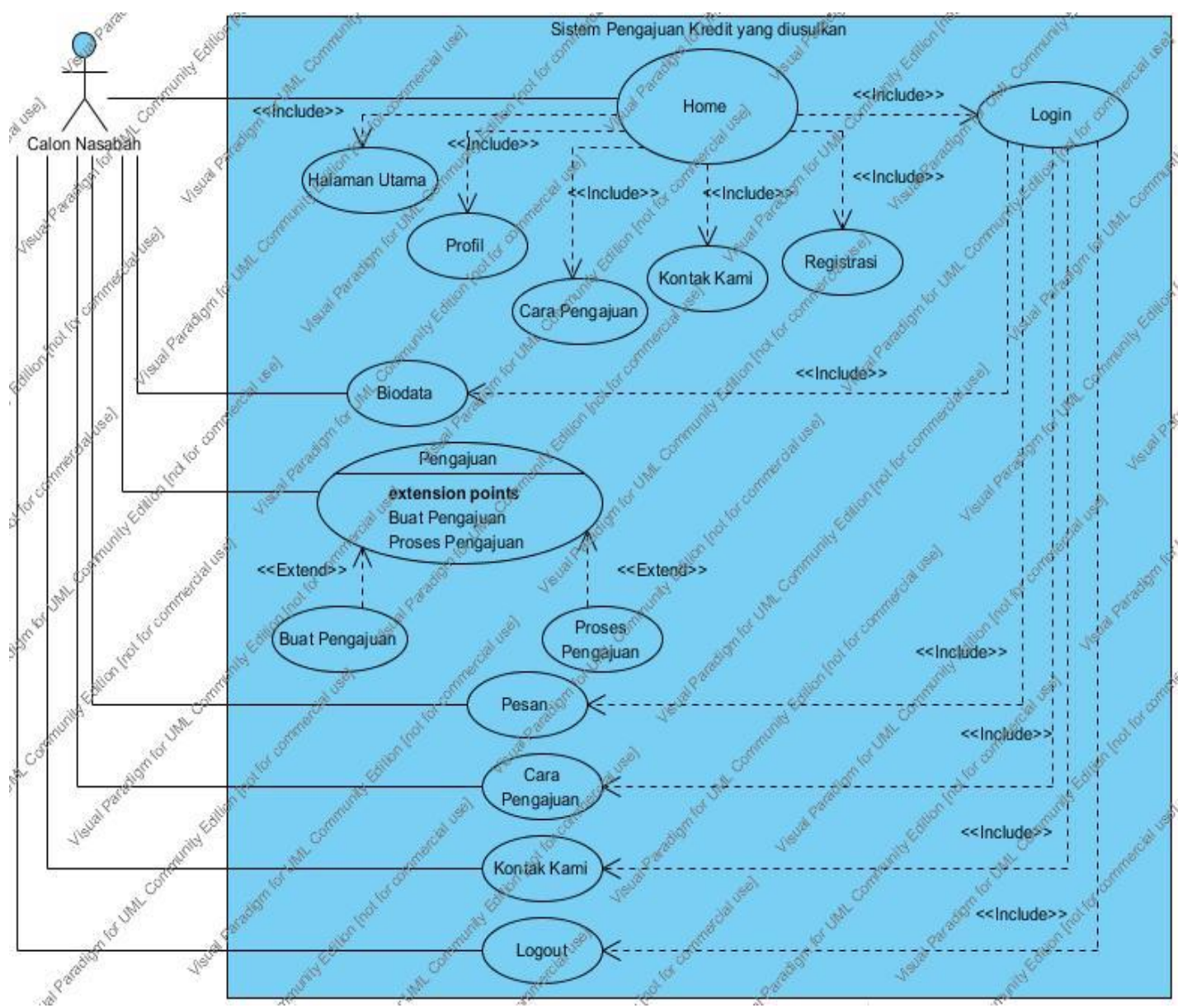

Gambar 3. Use case Diagram Sistem Prediksi

Berdasarkan dalam Gambar 3 Use Case Diagram Sistem Prediksi kelayakan kredit yang diusulkan saat ini, terdapat beberapa fungsi:

a. 1 system yang berfungsi mencakup kegiatan system kelayakan prediksi kredit.

b. 1 actor yang berfungsi melakukan di dalam sistem.

c. 15 use case yang berfungsi dilakukan oleh actor.

d. 2 extended yang meliputi buat pengajuan dan proses pengajuan.

e. 12 include.

\subsubsection{Implementasi}

Sistem penentuan prediksi kelayakan kredit nasabah berupaya menganalisa dengan cara input data atau aliran data secara sistematis dan terkontrol pada proses atau transformasikan data, menyimpan data, menghasilkan informasi serta terdapat form analisa penilaian kriteria dan perhitungan AHP (Analytical Hierarchy Process). 
PETIR: Jurnal Pengkajian dan Penerapan Teknik Informatika Vol. 13, No. 1, Maret 2020, P-ISSN 1978-9262, E-ISSN 2655-5018

\section{Tampilan Prototype Program}

\section{a. Tampilan Login}

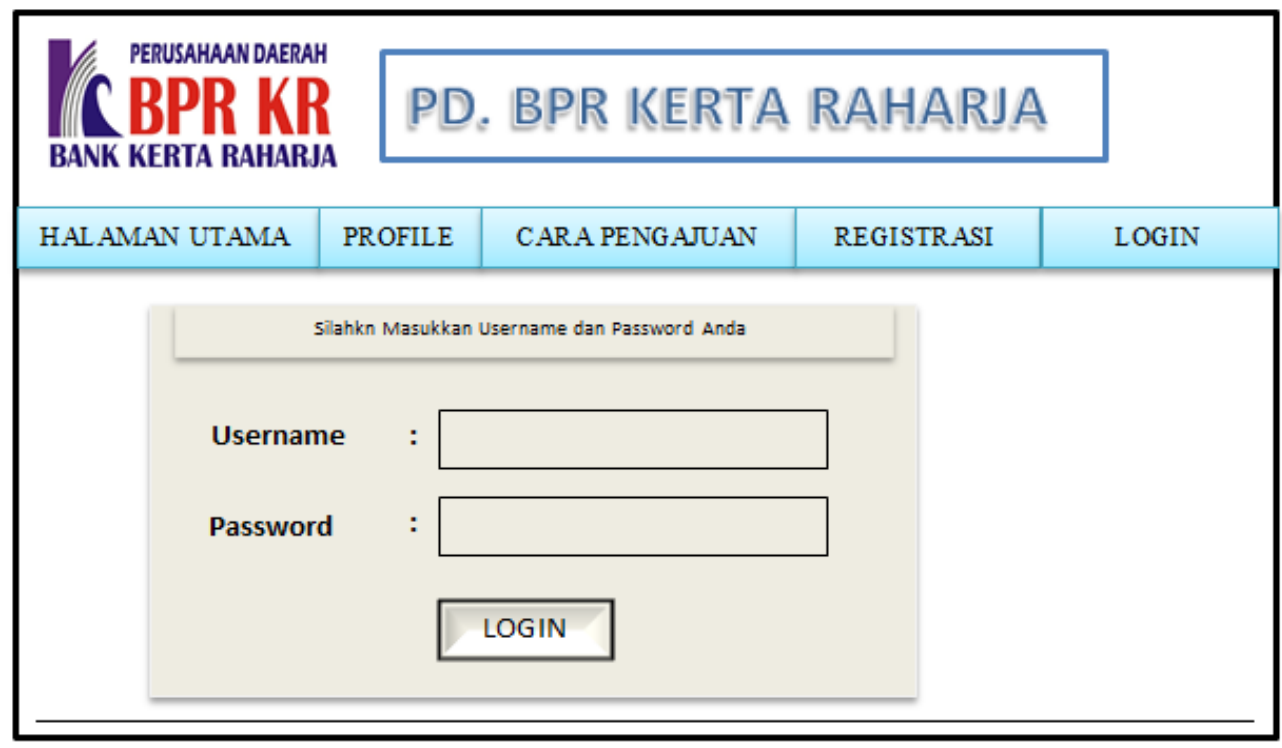

Gambar 4. Tampilan Halaman Login

Pada gambar 4 menjelaskan bahwa halaman login seorang calon nasabah dengan melakukan tahapan masuk ke dalam formulir permohonan kredit. Dalam sistem login ini hanya nasabah yang sudah melakukan registrasi pendaftaran akun serta password yang dicantumkan sehingga tingkat keamanan pun terjaga dan orang tidak bertanggung jawab tidak akan bisa masuk ke dalam sistem tersebut.

\section{b. Tampilan Halaman Formulir Permohonan Kredit}

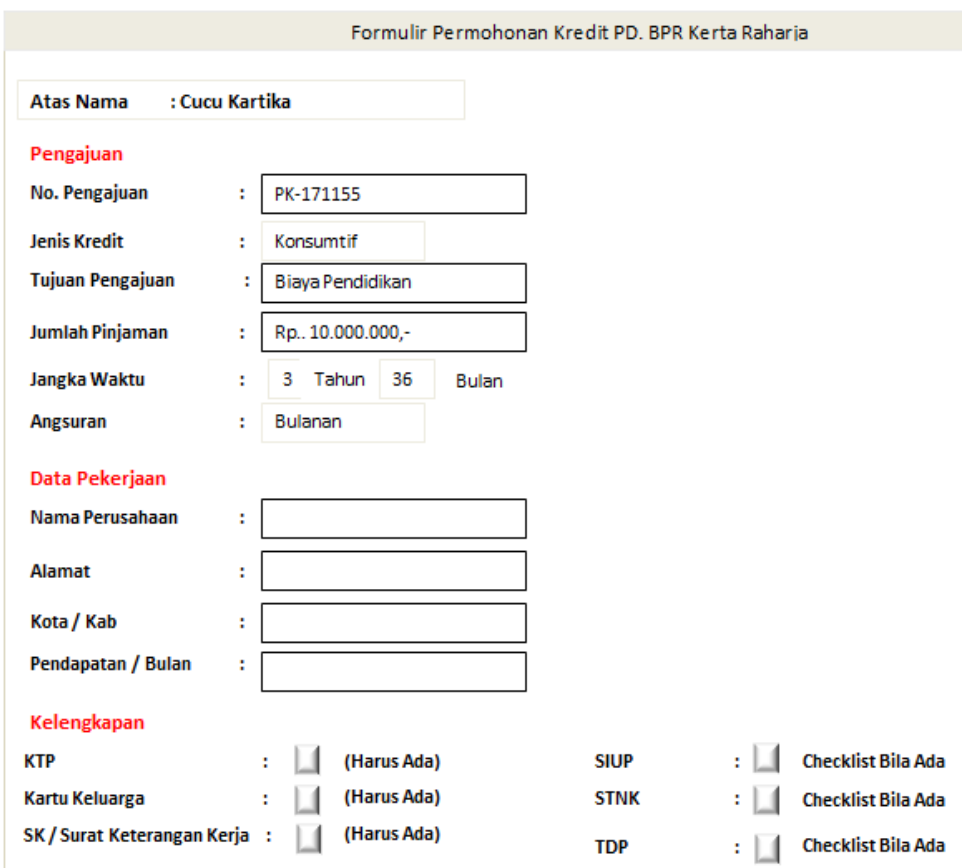

Gambar 5. Tampilan Halaman Formulir Permohonan Kredit. 
PETIR: Jurnal Pengkajian dan Penerapan Teknik Informatika Vol. 13, No. 1, Maret 2020, P-ISSN 1978-9262, E-ISSN 2655-5018

DOI: https://doi.org/10.33322/petir.v13i1.870

Pada gambar 5 menjelaskan halaman formulir permohonan kredit untuk seorang calon nasabah dengan melakukan pengisian formulir yang tersedia dalam web. Dalam sistem formulir permohonan kredit ini hanya calon nasabah yang sudah melakukan registrasi melalui pendaftaran akun serta password sebelumnya.

\section{c. Tampilan Form Analisa Kriteria Penilaian Pemberian Kredit}

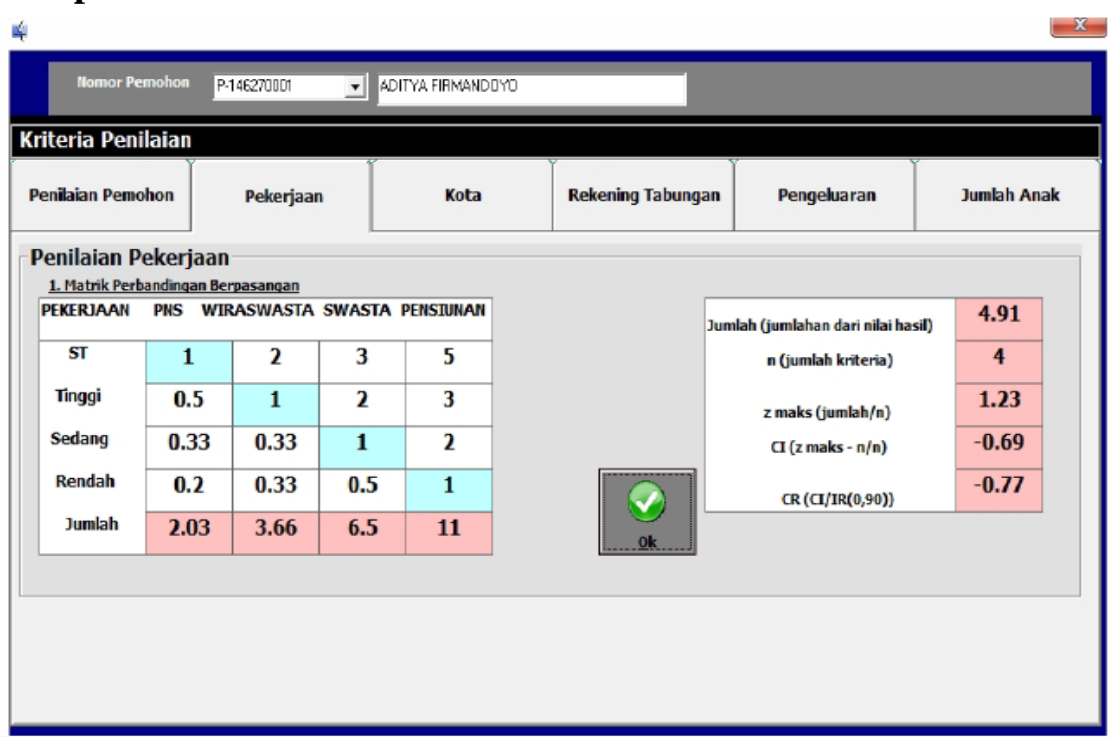

Gambar 6. Tampilan Form Analisa Kriteria Penilaian Pemberian Kredit

Pada gambar 6 menjelaskan bahwa kriteria penilaian kepada data nasabah calon kreditur sudah OK.

\section{d. Tampilan Perhitungan AHP (Analytical Hierarchy Process)}

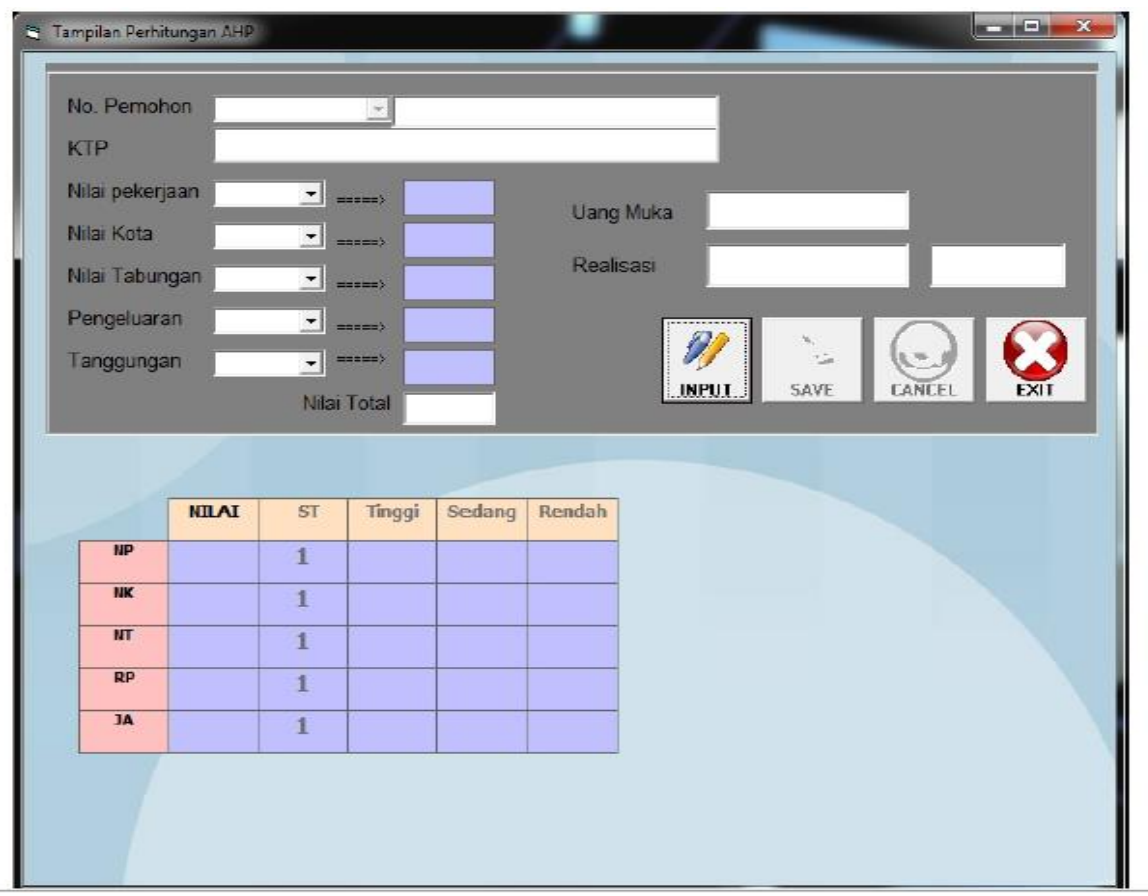

Gambar 7. Tampilan Perhitungan AHP 
Pada gambar 7 dapat dijelaskan bahwa system penentuan kelayakan kredit nasabah menggunakan metode AHP (Analytycal Hierarchy Process) berisi tentang input terlebih dahulu data pemohon dan terdapat penilaian kriteria yang nantinya sebagai acuan keputusan kredit.

\section{KESIMPULAN}

Berdasarkan dari hasil penelitian serta pembahasan yang telah dilakukan oleh penulis massa lampau maka penulis dapat mengambil kesimpulan dari hasil pengujian sistem yang telah dilakukan, maka bisa diambil beberapa kesimpulan diantaranya sebagai berikut dibawah ini:

1. Dalam suatu proses penentuan prediksi kelayakan kredit nasabah, sering kali Account Officer kredit tidak memberikan keputusan penentuan kelayakan kredit sebagai mana mestinya, dimana terdapat beberapa nasabah yang memiliki factor saudara atau kekeluargaan dengan Account Officer kredit kemudian guna mendapatkan sebuah prioritas utama atau tertinggi tanpa mementingkan serta menelaah bobot dari masing-masing nasabah tersebut.

2. Sistem Penentuan Prediksi kelayakan Kredit nasabah pada PD BPR Kerta Raharja ini sangat membantu pihak Account Officer bank dalam menentukan prediksi kelayakan nasabah penerima kredit dengan cara menghitung dan mengambil nilai hasil akhir perbandingan nasabah dengan prioritas Utama atau tertinggi dari penilaian bobot dan kriteria.

3. Tampilan aplikasi dalam berbentuk grafis yang sangat user friendly yang dapat membuat pengguna lebih mudah dalam pemakaian serta nyaman dalam penggunaan aplikasi ini. Sistem ini hanya menjadi alat bantu bagi pengambil keputusan penentuan kelayakan kredit nasabah, keputusan akhir tetap berada di tangan pengambil keputusan.

\section{DAFTAR PUSTAKA}

[1] F, Kiki., Windarto, A.P, Solikhun, \& L.M, Ridwan. Analisa Spk Dengan Metode Ahp Dalam Menentukan Faktor Konsumen Dalam Melakukan Kredit Barang. KOMIK (Konferensi Nasional Teknologi Informasi dan Komputer). Vol. 1, No. 1, Oktober 2017.

[2] G, Agerti. Traditional Models Used in Evaluation of Requests for Credit Card and Alternatives (AHP). Journal of Educational and Social Research. Vol. 7 No. 1, January 2017.

[3] X, Wenging., Y, Huiqun., G. Jianmei, S. Jinglei \& S. Huaiying. Credit Evaluation of Gas Consumers by Combining Hierarchy Analysis with Clustering. IEE Computer Society. Wuhan, China. pp. 24-26, May 2017.

[4] E, Nuri Latifa \& S, Jijon Raphita. Pengajuan Kredit Sepeda Motor Menggunakan Analytical Hierarchy Process (Studi Kasus Showroom Yoyo). Jurnal Nasional Komputasi dan Teknologi Informasi Vol. 1 No. 2, Oktober 2018.

[5] M, Roohollah., B, Bijan., N, Tahereh \& S, Mahshid. Credit Ranking of Bank Customers (An Integrated Model of RFM, FAHP and K-means). European Online Journal of Natural and Social Sciences; pp. 564-571. Vol. 3, No. 32014.

[6] M, Xiaoxing. Buils the Structural Model of Risk Assessment on the AHP Method by Yaahp Software: A Case Study on Housing Fund. Journal of Applied Science and Engineering Innovation. pp. 212-215, Vol. 2 No. 6, 2015.

[7] R, Malihe., A. Goudarzi, \& Z.M. Madanchi. Defining Balanced Scorecard Aspects in Banking Industry Using FAHP Approach. International Journal of Economics and Business Administration, pp. 25-38, Vol. 1, No. 1, 2015. 
PETIR: Jurnal Pengkajian dan Penerapan Teknik Informatika Vol. 13, No. 1, Maret 2020, P-ISSN 1978-9262, E-ISSN 2655-5018 DOI: https://doi.org/10.33322/petir.v13i1.870

[8] F, A.F Fernando \& S, P. Sergio. Comparing Trade-Off Adjustments In Credit Risk Analysis Of Mortgage Loans Using AHP, Delphi And MACBETH. International Journal Of Strategic Property Management. pp. 44-63, Vol. 20, No. 1, 2016.

[9] K, Khalil \& K, Kamal. Customer Classification In Banking System Of Iran Based On The Credit Risk Model Using Multicriteria Decision-Making Models. Contents Lists Available At Growing Science Accounting. pp. 177-184, Vol. 22016.

[10] A.L, Youssef \& T, Mohamed. Assessing the performance of microfinance lending process using AHP-fuzzy comprehensive evaluation method: Moroccan case study. International Journal of Engineering Business Management. pp. 1-11, Vol. 9, 2017.

[11] E.L, Yosi \& E.A.B.E.M. Nazri. Credit scoring models: Techniques and issues. Journal of Advanced Research in Business and Management Studies. pp. 29-41, Vol. 7, Issue 2017.

[12] B, Jan. Methodology for assessment of the accessibility of a brown coal deposit with Analytical Hierarchy Process and Weighted Linear Combination. Environ Earth Sci. pp. 74:4119-4131 2015.

[13] T, Recep. Performance Assessment In Banking Sector Through Analitical Hierarchy Process: Th e Case Of Public Banks, Private Commercial Banks And Participation Banks. Afro Eurasian Studies Journal., pp. 5-22. Vol. 4, Issue 1 and Spring 2015.

[14] R, Mohammad \& K, Saeedeh. Ranking the Banks through Performance Evaluation by Integrating Fuzzy AHP and TOPSIS Methods: A Study of Iranian Private Banks. International Journal of Academic Research in Accounting, Finance and Management Sciences. pp. 19-30. Vol. 6, No. 3, July 2016.

[15] J.M. Fallah. Prioritization of the Factors Affecting Bank Efficiency Using Combined Data Envelopment Analysis and Analytical Hierarchy Process Methods. Hindawi Publishing Corporation Journal of Optimization Vol. 1, 2016.

[16] Angelina, S.R. Damayanti., dkk. Application Selection Lending Houses Subsidized by the Method of AHP and SAW. MECNIT 2018 IOP Conf. Series: Journal of Physics: Conf. Series 12302019. 